\title{
Twinship in Mythology and Science: Ambivalence, Differentiation, and the Magical Bond
}

\author{
Benjamin Beit-Hallahmi and Maria Paluszny
}

$\mathbf{F}^{\prime}$ AMILY RELATIONSHIPS, especially the disruptive potential of libidinal and aggressive drives within the nuclear family, are among the most common themes of mythology. The theme of twinship in mythology can be seen as the focus of real and projected psychological tensions and their imagined or preferred solutions. Mythological fascination with twins and twinship and some parallels between ancient and modern theories of personality development in twins have been reviewed by Ortmeyer. ${ }^{1}$ We have attempted to show continuities between mythological traditions of twinship and common themes in modern research on twins. The common psychological elements in mythology, magic, and science as they deal with twinship are related to seemingly universal ambivalence and fascination with regard to multiple human births.

The myths and beliefs discussed here express two kinds of ambivalence toward twinship. One is the ambivalence toward the event of twin birth itself, its implications for theories of conception and paternity, and its social and economic consequences. Another is the ambivalence in the relationship between twins that brings forth on the one hand closeness and intimacy, and on the other extreme rivalries and hostilities. Elements of either or both kinds of ambivalence are found in myths, beliefs, and customs pertaining to twins. There are also attempts at solving this ambivalence through emphasizing either the positive or negative side in the relationship.

Twin birth is a challenge to primitive and infantile theories of conception and birth. Mythological theories of twin conception include the notions of double paternity or divine paternity; often these two are combined. Divine paternity puts twin birth in the category of the miraculous and mysterious, but it may also be regarded as a bad omen, being rare and therefore frightening and misunderstood. There is often a basic differentiation in mythological twinship-that of primogeniture. Because of the importance of determining the exact birth order, primacy often became a bone of contention. The disruption of the primogeniture system is one major reason for ambivalence toward the occurrence of twin birth. $\Lambda$ nother reason is economic. In primitive societies, having twins meant having two mouths to feed instead of the one that was expected. This realistic concern adds to whatever less rational fears are aroused by the occurrence of multiple births. This realistic concern about economic consequences is also the source of some ambiva-

From the Institute for Human Adjustment and the Institute for the Study of Mental Retardation and Related Diseases, University of Michigan, and the University of Michigan Medical School, Ann Arbor. Mich.

Benjamin Beit-Hallahmi, Ph.D.: Clinical Psychologist, Institute for Human Adjustment: Research Associate in Psychiatry, University of Michigan Medical School. Maria Paluszny, M.D.: Assistant Professor of Psychiatry, University of Michigan Medical School; Program Director in Psychiatry, Institute for the Study of Mental Retardation and Related Diseases, University of Michigan.

Reprints may be obtained from Dr. Paluszny, University of Michigan Medical School, Ann Arbor. Mich. 48104 .

(G) 1974 by Grune \& Stratton, Inc. 
lence in modern societies. Often the joy and pride in the birth of twin offspring are mixed with realistic worries. Vieth ${ }^{2}$ gives an example of a high level of ambivalence and shame regarding twin birth, coupled with a high level of technological progress, as it exists in Japan to this day.

Myths of intense competition between twins may reflect the realities of the struggle for survival in a primitive society. If twins are born in a subsistence culture with a high rate of infant mortality, quite often only one will survive. One role of the myth, then, would be to provide an explanation for the survival of this particular twin and to help in overcoming grief and guilt. Preoccupation with twinship in mythology and magic is expressed in an enormous variety of traditions. ${ }^{3-5}$ Upon examining mythological tales of twinship, we decided to look at the dimensions of competition for power in the family and at psychological differentiation and psycholugical support between twins.

We have selected two strikingly different views of twinship in mythology: the Old Testament view and the view of Greek mythology. As we will show, these two differing views have had an impact on modern thinking and in themselves present a fascinating study in contrasts. While the Old Testament emphasizes differentiation and competition between the twins, the Greek tradition is the source of the view of fusion and closeness in twin personalities.

\section{TWINS IN THE OLD TESTAMENT}

Sibling rivalry myths describing fraternal struggles are common in all cultures. ${ }^{6}$ Rank $^{7}$ regards the twin saga as a combination of the birth of the hero myth and the common myth of hostile brothers, and as an elaboration of the simple hero myth. The twin myth can be regarded as an accentuation of the fraternal hostility theme, and in most cases they contain indications of clear victory of the hero against the competing twin.

The Old Testament is the source for the clearest example of the good-twinbad-twin theme and the beginning of the tradition of psychological differentiation in the context of sibling rivalry and twin rivalry. Twin birth in the Old Testament is included in the category of miracles, occurring as a result of divine intervention; but it was also disruptive and fateful. Competition for the birthright starts in the womb, and the younger twin wins it from his slower, older brother. The victory of the younger son is another miracle and portends future greatness for his descendants. Divine intervention in the birth of the hero is rather indirect in Old Testament mythology. Nevertheless, many Old Testament heroes were born only after some contact between their mothers and God, and the mothers had been typically barren before. The divine intervention takes the form of a response to the mother's prayer or an actual visitation by angels.

The book of Genesis contains two cases of twinship in which twin birth was seen as both miraculous and disruptive. The first and best known twins were Jacob and Esau. They were the sons of Isaac, whose own birth was described as a miracle, the result of divine intervention, ${ }^{7}$ and who was later miraculously saved from filicide. The birth of the twins Jacob and Esau was also the result of divine intervention. They were born only after Isaac "entreated the Lord for his wife because she was barren" (Genesis, XXV, 21). Competition in this case starts in the womb even before birth. After "the children struggled together within her" (Genesis, XXV, 
22), Rebekah received a divine prophecy proclaiming that the two twins represented two nations and that the older should serve the younger. "Two nations are in thy womb, And two pcoples shall be separated from thy bowels; And the one people shall be stronger than the other people; And the elder shall serve the younger" (Genesis, XXV, 23).

Jacob later bought Esau's birthright for a mess of potage and then defrauded his father Isaac in order to receive the paternal blessing that was meant for Esau. The connection between being the second born and gaining the mother's love is clear in the case of Jacob and Esau. Jacob, the younger twin, became his mother's favorite and then was helped by her in winning the birthright.

Jews as a group have been identified with Jacob (who was later named Israel), the younger one, the ambitious underdog fighting against insurmountable odds. They have also sought to defend themselves against possible references to Jacob's dishonesty in dispossessing his twin brother. Talmudic legends emphasized and exaggerated the early differences between Jacob and Esau. Jacob was described in these legends as interested in learning, devout and modest. Esau was described as pagan, ignorant, cruel, and dishonest. Jacob and Esau took on the images of the good twin and the bad twin in legend and literature. As Brenner ${ }^{8}$ suggests, the story of Jacob and Esau was used as a rationalization and justification for the dispossession of Canaanite peoples. The stories of Isaac and Ishmael and Jacob and Esau described the ancestors of other peoples as being related to the Israelites but not sharing their birthright. Hostility toward the Edomites was especially strong and was rationalized by the story of Jacob and Esau. The hostility toward the Edomites was still felt in the New Testament story of the mythical King Herod. The historical King Herod was a descendant of converted Fdomites, and Jewish hostility toward him was expressed by casting him in the role of the evil king in the New Testament.

The birth of the second pair of twins in the Old Testament, Pharez and Zarah, came only one generation after the first. Brenner ${ }^{9}$ pointed out the prominence of fraternal rivalry in Genesis and suggested a continuity of this theme over the three successive generations of Jacob, his son Judah, and Judah's sons, building up to a climax. The rivalry between Jacob and Esau, then the rivalry between Joseph and his brothers, among them Judah, and then the rivalry between Er and Onan that led to Onan "spilling his seed on the ground" and to his death all culminated in the story of Tamar and Judah and the birth of another pair of rival twins.

That story created a famous riddle, which according to Jewish legend was one of the Queen of Sheba's riddles to King Solomon: "A woman was wedded to two and bore two sons, yet the four had one father." essence of the story - a combination of irregular death, marriage, sex, and birth. Judah, son of Jacob, had three sons, Er, Onan, and Shelah. Tamar was married to Er, who was slain by God, and then married Onan in a levirate marriage. Since under the rule of levirate marriage any offspring would be regarded as Er's, Onan spilled his semen on the ground to prevent conception and then was also slain by God. Tamar then had to wait for the third son, who was still a child, to marry her. Tired of waiting, Tamar dressed up as a harlot, covered her face, and seduced her father-in-law, keeping his signet, cord, and staff, which he gave her as a pledge. Tamar became pregnant and was about to be burned alive when she produced the 
evidence that implicated Judah. Judah acknowledged them and admitted his responsibility. When Tamar gave birth to twins, their struggle for primacy started in the womb, as the text relates, "And it came to pass, when she travailed, that one put out his hand; and the midwife took and bound his hand a scarlet thread, saying, 'This came out first.' And it came to pass, as he drew back his hand, that behold his brother came out; and she said 'How hast thou broken forth'? This breach be upon thee'; therefore his name was called Pharez. And afterward came out his brother, that had the scarlet thread upon his hand; and his name was called Zarah" (Genesis, XXXVIII, 28-30).

The consequences of the complicated and miraculous birth of Pharez and Zarah are momentous and far reaching. The descendents of Pharez, the younger twin who won the primacy, became nine generations later the kings of Judea. The House of David, the anointed king, sprang out of the loins of Pharez. In both Jewish and Christian mythology, the Messiah was to be a scion of the House of David and "a rod out of the stem of Jesse" (Isaiah, XI, 1). The agreement between Old Testament and New Testament mythology, stemming from the belief in messianic continuity, makes Pharez one link in the mythic genealogy of Jesus, as St. Matthew makes clear (St. Matthew, I, 3). While Pharez, who "stole" the birthright, became the ancestor of kings, Zarah, the firstborn, did not distinguish himself in any way.

The victory of the younger twin in mythological stories calls for an explanation. Campbell ${ }^{3}$ emphasized the casting of the hero in the role of the handicapped child who must surmount considerable odds before fulfilling his destiny. That is why the hero was often the younger son, an orphan, a step-child, or an "ugly duckling" in other forms. Being the younger twin may thus be interpreted as one manifestation of the danger faced by the hero-child, who has to overcome a variety of mishaps and ordeals to ensure mere survival.

Schlossman has offered a different answer to the question of the younger brother's victory, pointing out that in all cases of competition between two brothers in the book of Genesis (Cain-Abel, Isaac-Ishmael, Esau-Jacob, etc.), the older brother appeared to be the inferior or was finally rejected in favor of the younger. According to Schlossman, these stories reflected an archaic custom of sacrificing the firstborn. The firstborn was often considered as an offspring of the diety and beyond the claim of his earthly parents. This explanation fits the indirect indications of divine paternity in Genesis and the more direct expressions of divine paternity in other twin myths. The emphasis on the survival and victory of the younger twin may be also an expression of denial and wishful thinking. The younger may in reality be the weaker, and the myth denies this danger to his survival.

\section{GREEK MYTHOLOGY}

Greek mythology gives expression to the divine paternity and the double paternity theories of twin conception and also gives the clearest examples of harmony and devotion between twins. Ambivalence and complicated paternity myths cause the definition of twins to stretch in mythological accounts. Thus the best known pair of twins in western mythology, Castor and Pollux, who gave their names to the Gemini constellation of stars and to the Gemini sign of the zodiac, 
were not technically twins. The story of the conception of Castor and Pollux and the Dioscuri (sons of Zeus) expresses the ambivalence and confusion caused by twin birth.

Castor and Pollux were born as a result of two successive impregnations: Zeus fell in love with Leda, wife of Tyndareus, and approached her in the form a white swan. Leda also copulated with her husband on the same night and gave birth to four children, who came out of two eggs. Pollux and Helen came out of one egg, fathered by Zeus, and Castor and Clytemnestra canle out of the second egg, fathered by Tyndareus. Despite their divided fraternity, the two half-brothers were regarded as Dioscuri, as twins, and as close friends. At the same time, Helen (of Troy) and Clytemnestra were regarded as sisters only. Greek legends describe the devotion of the Dioscuri to each other and their inseparable fates in life and beyond. The account of the twin birth in this case can be regarded as expressing the basic ambivalence toward unusual birth and the doubts it raises regarding the validity of primitive theories of paternity. The fantasies that twins have two separate fathers and that twin birth is the result of two separate conceptions are expressed in this myth. These fantasies are elaborated and condensed by changing the mode of birth from human parturition to egg laying.

The miraculous aspect of twin birth is elaborated through the description of two eggs containing two children each. The double miracle is doubled again. It is interesting to note that Frazer ${ }^{4}$ reports the primitive custom of counting twins and their afterbirths as four children. That the two eggs in the story represent twins becomes clear later when Castor and Pollux emerge as Dioscuri, the heroes of the myth. The two females, Helen and Clytemnestra, are relegated to a secondary role. The two male heroes are worshiped and immortalized as the patrons of sailors and hospitality, and as symbols of brotherly love. In the case of Castor and Pollux, immortality becomes the equivalent of primogeniture. Pollux the immortal was the only truly divine twin, but his superiority did not become the cause for conflict.

The theory of twin birth as caused by two separate and successive conceptions is again expressed in the story of Hercules and Iphicles. Zeus, wishing to have a son who would be the protector of both men and gods, descended to the city of Thebes, assumed the appearance of Amphitryon, and impregnated Amphitryon's wife, Alcmene. Amphitryon himself returned soon afterward and impregnated his wife again. From these two unions the twins Hercules and Iphicles were born. Only Hercules, the divine member of the pair, was praised and worshiped. The story of Hercules contains all the typical elements of the hero myth (cf. Rank ${ }^{7}$ ). Iphicles on the other hand was in no way similar to Hercules, but later became the father of his best friend, Iolaos. He was not only a mortal but was conceived and born 1 day later.

Amphion and Zethus were another pair of semi-divine twins born to the nymph Antiope and fathered by Zeus. The story of their birth is a typical hero myth and parallels the Roman story of Remus and Romulus. ${ }^{7}$ Zeus approached Antiope in the form of a satyr and surprised her in her sleep. As with many other mythological heroes, the divine paternity was followed by a delivery in the open, exposure to the elements, and salvation by shepherds. Amphion and Zethus lived harmoniously, founded the city of Thebes, and fought side by side to defend it.

The twins Apollo and Artemis were the most important in the Greek pantheon 
and the only mixed pair. They were born to Leto from her union with Zeus and were victims of Hera's jealousy even before they were born. Because of Hera's machinations, the birth was delayed and complicated. According to one tradition, they were born at the same time; according to another, Artemis was born first and then served as a midwife during her brother's birth. In the case of Apollo and Artemis, harmony between twins was followed by independence and individuation. According to one little-known version of the Narcissus story, Narcissus had a twin sister whom he lost; it was not with himself that Narcissus fell in love, but with his twin sister. After she died, he had to console himself by looking at his own reflection in the water, the reflection that was the likeness of the beloved twin.

As Ortmeyer ${ }^{1}$ pointed out, Greek mythology saw the two twins as a unity, one personality created by two complementary entities. Ortmeyer related this myth to Plato's explanation of the love between the sexes, which suggested an original unisexed person that was split into the two sexes, who are still seeking the original entity.

All the stories of twins in Greek mythology emphasized the unique bond between twins, expressed in harmony and love. Despite the fact that Greek traditions abounded with stories of sibling rivalry, twins were portrayed as the exceptions to rivalries and jealousies. The confusion surrounding the birth of twins was resolved by seeing it mostly as a miracle. The contrast between twin stories in the Old Testament and in Greek mythology is rather striking.

A common thread in Old Testament stories and Greek mythology is the predestination of one of the twins to a fate involving greatness, victory, and immortality, either directly or through his descendents. The predestination and dichotomy themes are strong expressions of the idea of psychological differentiation. If only one twin is destined for greatness, then the twins are never identical or equal. This view is in clear opposition to the primitive idea of a common soul for the two twins. It may be seen as a forerunner of the Western emphasis on the individual and his destiny. Both Campbell ${ }^{3}$ and Rank ${ }^{7}$ interpret several twin myths as representing the story of one early hero, with the other twin being a later addition.

\section{TWINSHIP IN MODERN SCIENCE}

Today we no longer are concerned about the question of twin paternity, though there are still questions about twin conception. " Twin birth is still a miracle-for the researchers who attempt to unlock some of the most baffling mysteries of human behavior. Twins have become the miraculous natural laboratory for studying the relative importance of heredity and environment, the modern equivalents of divinely inspired fate and human actions.

Despite many anecdotal reports of the magical bond expressed through empathy and unusual sensitivites (Ortmeyer, ${ }^{1}$ among many others), systematic studies of unusual twin communications are rare. Bloch ${ }^{12}$ found support for the notion of greater similarity in the subjective experiences of $\mathrm{MZ}$ twins as compared to $\mathrm{DZ}$ twins and singletons. Barron and Mordkoff ${ }^{13}$ did not find any evidence for the existence of extrasensory sensitivity in pairs of identical twins.

The best-known studies using twins are those that were done to show the importance of heredity in the etiology of schizophrenia, ${ }^{14-18}$ criminal behavior, ${ }^{19}$ suicide, ${ }^{20}$ and neurosis. ${ }^{21,22}$ Fewer twin studies have dealt with the heritability of more 
positive qualities. ${ }^{2324}$ The high concordance rates for schizophrenia in twins found in the earlier studies ${ }^{16}$ were seen as supporting a biological-hereditary explanation of its etiology. They have also been confused with a higher incidence of schizophrenia in twins, causing undue anxiety. Later studies showed lower concordance rates ${ }^{15}$ and an incidence rate of schizophrenia in twins that was equal to that of the general population. ${ }^{14}$ Clinical case studies of psychopathology in twin pairs also have emphasized the weight of genetic commonality and genetic makeup in bringing about such varied disorders as obsession and post-partum psychosis. ${ }^{25.26}$

The mythological notions of separation and primacy and the division into the good and bad members of the twin pair have modern parallels in research on birth order and birth weight in twins. Whereas in mythology primacy is critical in the good-twin-bad-twin concept, with the younger, second-born twin usually being seen as the good twin, in scientific writings the firstborn is frequently seen as the one less prone to psychiatric disturbance. Although being firstborn is still considered important by some investigators, the majority of investigators consider the birth weight as being the crucial difference between the twins. ${ }^{27}$

Systematic studies have repeatedly pointed to the later born or the lighter in birth weight as the more vulnerable of the twins. ${ }^{24-31}$ The smaller twin (and frequently the second-born) is often seen as the more dependent and vulnerable and likely to develop psychosis ${ }^{32}$ or another type of psychiatric disturbance, ${ }^{27}$ while the larger and usually the firstborn twin is frequently described as more independent, less vulnerable, and less susceptible to a psychiatric disturbance.

Gifford et al..$^{33}$ found that the twin who was larger at birth was quieter and more independent, developed more rapidly, had fewer eating problems, and was identified with the father. The smaller twin was found to be more verbal and more social and more identified with the mother. The weaker and smaller twin at birth, who is expected to prevail in the Old Testament tradition, turns out to be the loser as viewed by modern science; and being the Jacob in the contemporary twin story, the weaker elicits a Rebekah's reaction on the mother's part, which becomes a mixed blessing. Allen et al. ${ }^{34}$ found that being closer to the mother is usually related to being the second-born, the smaller, or the neurologically inferior twin. It seems that a small twin may be more vulnerable on the basis of physiological factors and also on the basis of different parenting. Parents with a smaller twin frequently react by being overly solicitous and thus fostering dependency and vulnerability ${ }^{35}$ If we link vulnerability to psychiatric disorders with the concept of a bad twin, then we can readily see that in scientific writings, much as in mythology, there is a bad twin and a good twin.

The psychoanalytic view of twinship combines elements of both mythological traditions, but tends to be on the side of a differentiation and separation. It recognizes hostility and competition and warns against fusion. ${ }^{36-40}$ Rivalry, coupled with mutual dependency and the formation of separate identities, has been the major focus in psychoanalytic studies of twins. Burlingham, ${ }^{41}$ in her longitudinal studies of a pair of identical twins, Bill and Bert, described the dependency and rivalry from infancy through childhood, adolescence, and into adulthood. As babies, these twins "grabbed, hit and screamed until one let go, crying with temper and frustration; pulling the twin down who was standing and then hitting and rolling on him was a frequent occurrence." Later, in adolescence, when one of the 
boys had a fight, the other one stated, "I was jealous of the other boy hitting Bill. I wanted to do it myself."

Frequently, either coupled with rivalry or as a separate problem, authors describe extreme dependency and even "part fusion of the self representation and the object representation . . . leading to diffuseness of ego boundaries between two people." ${ }^{22}$ This is well illustrated in a case of two 5-year-old twin girls trying on new dresses, where one said to the other, "Stand over there so I can see how I look." 4.3

Implications of modern scientific studies of twins in dealing with individual cases of twinship are complex. It is difficult to arrive at any clear-cut conclusions. Still, many studies leave the impression that twin birth is a complicated and ominous event. Some hereditary studies imply a common, inescapable fate. Clinical studies emphasize the difficulties in differentiation and individuation and the possibility of drawing other family members into the fusion. ${ }^{44}$

\section{SUMMARY}

This article has attempted to show parallels and continuities between mythological traditions dealing with twinship and modern scientific approaches that either study twinship itself or use twin studies to answer more general questions. We do not mean to imply that modern research on twins is just a continuation of mythological concepts. What we have tried to show is the continuity in some of the questions being asked and in some of the answers being given. The explanation we would like to offer here for these parallels is that there are common psychological elements in both mythological and scientific approaches to twinship. The two major elements are fascination and ambivalence. Fascination with twin births has always been combined with a great deal of apprehension and ambivalence. In both primitive and modern societies, multiple births have been viewed as a potential source of familial and social conflict and complication. The Old Testament mythological tradition, which emphasized competition and individuation in twin pairs, and the Greek mythological tradition, which emphasized fusion and intimacy, are both reflected in modern approaches to the study of twinship.

\section{REFERENCES}

1. Ortmeyer D H: The we-self of identical twins. Contemp Psychoanal 6:125-142, 1970

2. Veith 1: Twin birth: Blessing or disaster. A Japanese view. Int J Soc Psychiatry 6:230-236, 1960

3. Campbell J: The Hero with a Thousand Faces. New York, Pantheon, 1948

4. Frazer II G: The Golden Bough. I.ondon, Macmillan, 1922

5. Bonnerjea B: A Dictionary of Superstitions and Mythology. London, Folk Press, 1927

6. Kluckhohn $\mathrm{C}$ : Recurrent themes in myth and mythmaking, in Murray HA (ed): Myth and Mythmaking. Boston, Beacon Press, 1968

7. Rank O: The Myth of the Birth of the Hero. New York, Journal of Nervous and Mental Disease Publishing Co., 1914
8. Brenner AB: The covenant with Abraham. Psychoanal Rev 39:34-52, 1952

9. Brenner AB: Onan, the levirate marriage and the genealogy of the Messiah. J Am Psychoanal Assoc 10:701-721, 1962

10. Ginsberg L: The Legends of the Jews, vol 4. Philadelphia, Jewish Pub. Soc., 1913, p 145

11. Allen G, Schachter J: Do conception delays explain some changes in twinning rates? Acta Genet Med Gemellol 19:30-34, 1970

12. Bloch AA: Remembrance of feelings past: A study of phenomenological genetics. 74:340347, 1969

13. Barron F, Mordkoff AM: An attempt to relate creativity to possible extrasensory empathy as measured by physiological arousal in identical twins. J Am Soc Psychical Res 62:73-79. 1968 
14. Allen MG, et al: Schizophrenia in veteran twins: A diagnostic view. Am J Psychiatry 128:939-945, 1972

15. Fischer $M$, Harvald B, Hauge $M$ : A Danish twin study of schizophrenia. Br J Psychiatry 115:981-990, 1969

16. Kallman FJ: Heredity in Health and Mental Disorder. New York, W. W. Norton. 1953

17. Karlsson JL: Evidence for hereditary transmission of schizophrenia. J Schizo 1:239-256, 1967

18. Kringlen E: Schizophrenia in twins: An epıdemiological-clinical study. Psychiatry 29: 172-184, 1966

19. Christiansen KO: Threshold of tolerance in various population groups illustrated by results from Danish criminological twin study, in DeReuck A (ed): The Mentally Abnormal Offender. Boston, Little, Brown, 1968

20. Juel-Nielsen N. Videbech T: A twin study of suicide. Acta Genet Med Gemellol 19:307310,1970

21. Gottesman II: Differential inheritance of the psychoneuroses. Eugenics Quart 9:223-227, 1962

22. Gottesman II: Heritability of personality: A demonstration. Psychol Monogr 77:1-21, 1963

23. Mittler P: Genetic aspects of psycholinguistic abilities. J Child Psychol Psychiatry 10:165-176, 1969

24. Owen DR, Sines JO: Heritability of personality in children. Behav Genet 1:235-248, 1970

25. Kane FJ: Post-partum psychosis in identical twins. Psychosomatics 9:278-281, 1968

26. Marks IM, Crowe M, Drewe E, et al: Obsessive-compulsive neurosis in identical twins. Br J Psychiatry 115:991-998, 1969

27. Matheny AP, Brown AM: The behavior of twins: Effects of birth weight and birth sequence. Child Dev 42:251-257, 1971

28. Bruch $\mathrm{H}$ : The significant difference: Discordant incidence of anorexia nervosa in monozygotic twins. Am J Psychiatry 126:85-90, 1969

29. Scarr S: Effects of birth weight on later intelligence. Soc Biol 16:249-256, 1969
30. Stabenau JR, Pollin W: Early characteristics of monozygotic twins discordant for schizophrenia. Arch Gen Psychiatry 17:723-734, 1967

31. Stabenau JR, Pollin W: Adult protienbound iodine and maturity at birth in monozygotic twins. J Clin Endocrinol Metab 28:693699, 1968

32. Pollin W, Stabenau JR, Turpin J: Family studies with identical twins discordant for schizophrenia. Psychiatry 28:60-78, 1965

33. Gifford S, Murawski BJ, Brazelton TB, Young GC: Differences in individual development within a pair of identical twins. Int J Psychoanal 47:261-268, 1966

34. Allen MG, et al: Parental, birth and infancy factors in infant twin development. Am J Psychiatry 127:1597-1604, 1971

35. Pollin W, Stabenau JR, Mosher L, Tupin $\mathrm{J}$ : Life history differences in identical twins discordant for schizophrenia. Am J Orthopsychiatry 36:492-509, 1966

36. Burlingham DT: Twins: Observations of environmental influences on their development. Psychoanal Study Child 2:6l-73, 1946

37. Burlingham DT: Twins: A Study of Three Pairs of Identical Twins. London, Imago, 1952

38. Beckwitt $\mathrm{M}$ : On the vicissitudes of sibling penis envy in a girl twin. Isr Ann. Psychiatry 6:13-29, 1968

39. Damarest EW: The initial phase of concomitant treatment of twins. Psychoanal Study Child 10:336-352, 1955

40. Lidz T, Schafer S, Fleck S, et al: Ego differentiation and schizophrenic symptom formation in identical twins. J Am Psychoanal Assoc 10:74-90, 1962

41. Burlingham DT: A study of identical twins. Psychoanal Study Child 18:367-423, 1963

42. Joseph ED, Tabor JH: The simultaneous analysis of a pair of identical twins. Psychoanal Study Child 16:275-299, 1961

43. Leonard MR: Problems in identification and ego development in twins. Psychoanal Study Child 16:300-320, 1961

44. Cohen HA: A family with twins discordant for schizophrenia: A case study. J Proj Tech Pcrson Assess 33:542-548, 1969 